\title{
Pyramiding $B$ Genes in Cotton Achieves Broader But Not Always Higher Resistance to Bacterial Blight
}

\author{
Margaret Essenberg, Melanie B. Bayles, Margaret L. Pierce, and Laval M. Verhalen
}

First and third authors: Department of Biochemistry and Molecular Biology; second and fourth authors: Department of Plant and Soil Sciences, Oklahoma State University, Stillwater 74078.

Accepted for publication 5 March 2014.

\section{ABSTRACT}

Essenberg, M., Bayles, M. B., Pierce, M. L., and Verhalen, L. M. 2014. Pyramiding $B$ genes in cotton achieves broader but not always higher resistance to bacterial blight. Phytopathology 104:1088-1097.

Near-isogenic lines of upland cotton (Gossypium hirsutum) carrying single, race-specific genes $B_{4}, B_{I n}$, and $b_{7}$ for resistance to bacterial blight were used to develop a pyramid of lines with all possible combinations of two and three genes to learn whether the pyramid could achieve broad and high resistance approaching that of L. A. Brinkerhoff's exceptional line $\operatorname{Im} 216$. Isogenic strains of Xanthomonas axonopodis pv. malvacearum carrying single avirulence (avr) genes were used to identify plants carrying specific resistance $(B)$ genes. Under field conditions in north-central Oklahoma, pyramid lines exhibited broader resistance to individual races and, consequently, higher resistance to a race mixture. It was predicted that lines carrying two or three $B$ genes would also exhibit higher resistance to race 1, which possesses many avr genes. Although some enhancements were observed, they did not approach the level of resistance of $\operatorname{Im} 216$. In a growth chamber, bacterial populations attained by race 1 in and on leaves of the pyramid lines decreased significantly with increasing number of $B$ genes in only one of four experiments. The older lines, Im216 and AcHR, exhibited considerably lower bacterial populations than any of the one-, two-, or three- $B$-gene lines. A spreading collapse of spray-inoculated $\operatorname{Ac} B_{I n}$ and $A c B_{I n} b_{7}$ leaves appears to be a defense response (conditioned by $B_{I n}$ ) that is out of control.

Additional keywords: durable resistance, hypersensitive response, leaf surface, race-change mutant, runaway cell death, X. campestris pv. malvacearum, $X$. citri pv. malvacearum.
The idea of "pyramiding" (i.e., accumulating several genes for resistance to the same disease into a crop plant) was promoted by R. R. Nelson over three decades ago as a method for building durable resistance (26). In upland cotton (Gossypium hirsutum L.), immunity to bacterial blight was achieved by pyramiding two or three major resistance $(R)$ genes ( $B$ genes) onto a polygenic complex background $(3,6,7)$. The resistance is broad and durable: those lines have maintained their immunity to all Xanthomonas axonopodis pv. malvacearum (Smith) Vauterin et al. [=X. campestris pv. malvacearum (Smith) Dye, X. citri pv. malvacearum (ex Smith 1901)] races identified in the United States since the immune lines were developed more than 40 years ago (6). $\operatorname{Im} 216$ is one such line developed by L. A. Brinkerhoff; its successful hypersensitive responses in leaves to individual infection sites are so highly localized that they can be seen only with the aid of a microscope $(7,15)$. In $\operatorname{Im} 216$, bacterial multiplication is arrested more quickly after inoculation than in plants with lower levels of resistance $(30,34)$. Sesquiterpenoid phytoalexins accumulate in the hypersensitively responding cells to antibacterial concentrations shortly before the bacteria stop multiplying (30). We wanted to investigate what contribution individual $R$ genes make to achieve such exceptional resistance.

Although the parental lines from which $\operatorname{Im} 216$ was developed carried the major bacterial blight $R$ genes $B_{2}, B_{3}$, and $b_{7}$ as well as the polygenic complex $B_{S m}(7)$, the $R$ genes possessed by $\operatorname{Im} 216$

Corresponding author: M. Essenberg

E-mail address: margaret.essenberg@okstate.edu

* The $\boldsymbol{e}$-Xtra logo stands for "electronic extra" and indicates that the online version contains one supplemental figure accompanied by one explanatory supplemental text file. Figure 3 appears in color online.

http://dx.doi.org/10.1094/PHYTO-06-13-0167-R

(C) 2014 The American Phytopathological Society are not precisely known (6), nor is there a susceptible line nearly isogenic to it to facilitate investigation of its $R$ gene composition. The present work was undertaken to learn whether a pyramid of three major, race-specific $R$ genes in a near-isogenic background could achieve a similarly broad and high resistance to bacterial blight. Available for this work were near-isogenic lines (NILs) of upland cotton carrying the individual genes $B_{2}, B_{4}, B_{5}, B_{I n}, b_{6}$, and $b_{7}$ in the susceptible 'Acala 44' background (14; our unpublished work). Of these $B$ genes, molecular markers were known for only $B_{2}$ and $b_{6}$ (39). However, phenotypic selection was possible because each $B$ gene responds to a different set of the isogenic strains of $X$. axonopodis pv. malvacearum carrying the single avirulence ( $a v r$ ) genes developed by De Feyter and Gabriel (9). We chose to pyramid $B_{4}, B_{I n}$, and $b_{7}$ because each of those genes is race specific (i.e., each confers resistance only to strains of the pathogen carrying the corresponding gene avrB4, avrBIn, or $a v r b 7$, respectively), whereas $B_{2}$ and $B_{5}$ are less specific (9), and the resistance conferred by $b_{6}$ is quite low. Unless the three chosen genes exerted epistatic suppression of each other's activities, we expected each of the three isogenic bacterial strains to provide a specific test for the presence of its corresponding $B$ gene regardless of the presence or absence of the other two $B$ genes.

The pyramid lines were inoculated in the field with race 1 , which carries all three $a v r$ genes that were used to develop the pyramid, and with a race mixture that included races virulent against each of the three $B$ genes but none of which is virulent against all three. We expected that pyramiding the three $B$ genes would extend the breadth of resistance, so that the race mixture would produce smaller lesions in pyramid lines carrying at least one $B$ gene effective against each of the races. We also predicted that, as the number of $a v r$ gene- $B$ gene interactions increased from one to two and then to three, the level of resistance would increase in pyramid lines inoculated with race 1 . In this field 
study, we evaluated levels of resistance by recording lesion size (a measure of pathogenicity).

Resistance was also evaluated in growth chambers by determining bacterial populations attained in and on leaves (a measure of parasitism). A dilute inoculum concentration was chosen $(\approx 1 \times$ $10^{6} \mathrm{CFU} \mathrm{ml} \mathrm{m}^{-1}$ ) to avoid a confluent hypersensitive necrotic response and, instead, to elicit localized hypersensitive responses to individual bacterial colonies in leaves that remain turgid. Under this condition, the resistant response of cotton is bacteriostatic rather than bactericidal (15), and maximum populations are attained by 8 to 10 days after spray infiltration (34).

\section{MATERIALS AND METHODS}

Bacterial strains. During the development of the $R$ gene pyramid, screening of plants for individual $B$ genes was accomplished using four isogenic strains of $X$. axonopodis pv. malvacearum provided by D. W. Gabriel. Strain 1003/pUFR042 carries no $a v r$ genes and was derived from an African strain with a wider host range than any races identified in the United States (9). The other three isogenic strains each carry a single $a v \mathrm{r}$ gene in pUFR042: 1003/pUFR123 carries avrB4, 1003/pUFR156 carries avrBIn, and1003/pUFR163 carries avrb7 (10) (R. De Feyter and D. W. Gabriel, unpublished data). Strain 1003, from which these isogenic strains were developed, is more widely virulent than any $X$. axonopodis pv. malvacearum strain naturally found in the New World (9). To prevent their accidental release into the environment, all work with the isogenic strains was conducted under BSL-1-P or BSL-1 biosafety guidelines $(36,37)$.

Race 1 strain $\mathrm{H}$ was used with the isogenic strains during development of the $R$ gene pyramid because it was the source of the $a v r$ genes cloned into the isogenic strains $(9,10)(\mathrm{R}$. De Feyter and D. W. Gabriel, unpublished data). All other work described herein employed the more aggressive race 1 strain 3631 (14). It carries many $a v r$ genes and is avirulent in all three of the single$B$-gene NILs used in this work (14). The race mixture employed in the field consisted of race 1 strain $3631, \mathrm{KM} 1$, and race 10. KM1 is a spontaneous race-change mutant derived by McNally (24) from race 1 strain $\mathrm{H}(9)$. It is virulent against $R$ gene $B_{4}$ but is avirulent against $B_{I n}$ and $b_{7}$. The strain of race 10 we used was a gift from L. S. Bird. It is virulent against $B_{I n}$ and $b_{7}(5)$ but is avirulent against $B_{4}(4)$.

Cultures of all strains were maintained at $-70^{\circ} \mathrm{C}$ in $14 \%$ (vol/vol) glycerol in Bacto nutrient broth (Difco Laboratories, Detroit). For growth-chamber work, the isogenic strains and strain

\section{Number of $B$ Genes}

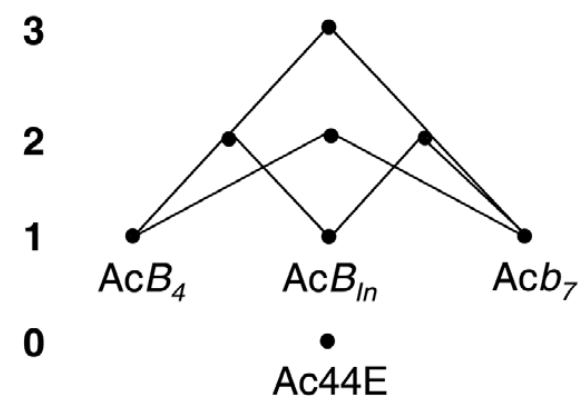

Fig. 1. Resistance gene pyramid. Solid circles indicate near-isogenic lines (NILs) on the susceptible Ac44E cotton background. The pyramid was built upward from one- $B$-gene NILs (14), using classical pedigree breeding methodology (1) and intensive screening with isogenic strains of Xanthomonas axonopodis pv. malvacearum (14). For each cross, the female parent is shown on the left. $\mathrm{Ac} B_{4} B_{I n} b_{7}$ was obtained from a cross of $\mathrm{Ac} B_{4} B_{\text {In }}$ with $\mathrm{Ac} b_{7}$.
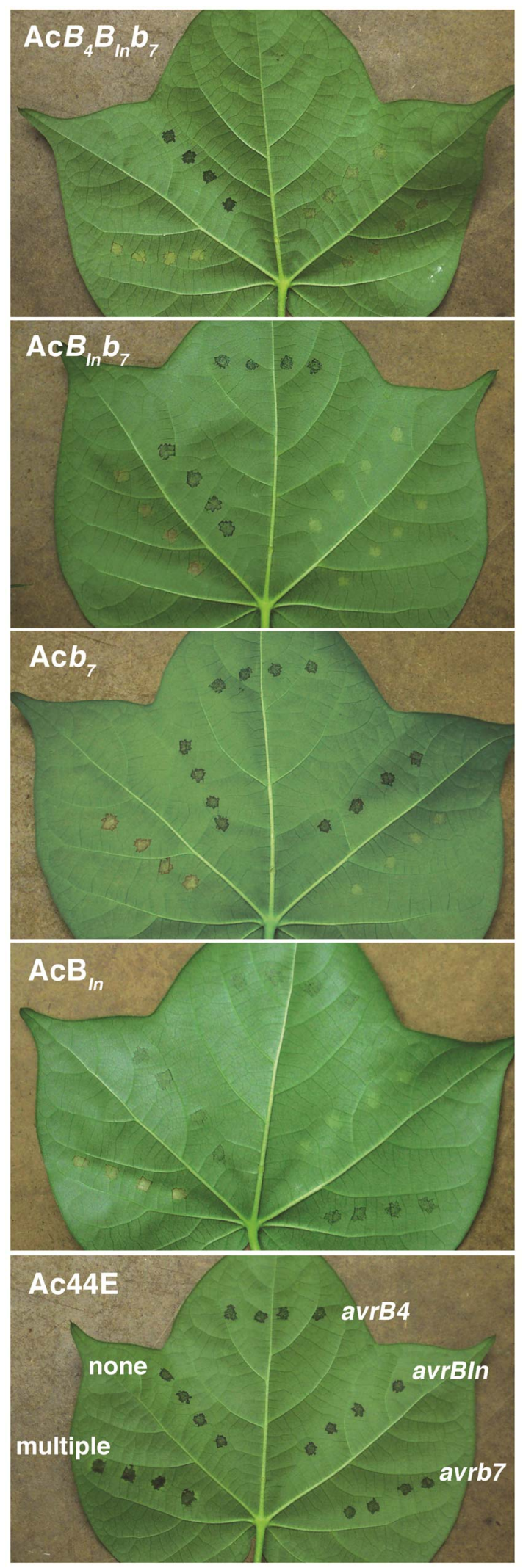

Fig. 2. Race-specific interactions in a growth chamber among selected nearisogenic lines of the $B$-gene cotton pyramid and strains of Xanthomonas axonopodis pv. malvacearum carrying the indicated avirulence (avr) genes. Representative leaves are shown for $\mathrm{Ac} 44 \mathrm{E}, \mathrm{Ac} B_{I n}, \mathrm{Ac} b_{7}, \mathrm{Ac} B_{I n} b_{7}$, and $\mathrm{Ac} B_{4} B_{I n} b_{7}$ which were spot-inoculated at $\approx 1 \times 10^{6} \mathrm{CFU} \mathrm{ml} \mathrm{m}^{-1}$, with five bacterial strains carrying multiple (race 1), no, or single $a v r$ genes. The latter four strains differ only in the presence or absence of a particular $a v r$ gene $(9,10)$ (R. De Feyter and D. W. Gabriel, unpublished data). The pattern of inoculation is indicated on the Ac44E leaf. The abaxial surface of each leaf was photographed 11 days postinoculation. 
$\mathrm{H}$ were cultured in peptone-yeast extract-glycerol-MOPS medium (11), and strain 3631 was grown in Xanthomonas-tryptone-yeast extract-glucose medium (8). Inocula for resistance testing in the field were prepared from nutrient broth cultures of strain 3631, $\mathrm{KM} 1$, or race 10 , as previously described (14). In each case, the strains were grown at $30^{\circ} \mathrm{C}$ on a rotary shaker at $200 \mathrm{rpm}$. Inocula were prepared from late-log-phase cultures by dilution in aqueous sterile, saturated $\mathrm{CaCO}_{3}$ solution to the desired densities.

Genetic stocks of cotton and breeding procedures. Parental lines used for $R$ gene pyramiding were the NILs $A c B_{4}, A c B_{I n}$, and $\mathrm{Ac} b_{7}$, which were previously developed in the Ac44E genetic background (14). Ac44E is a single plant selection from Brinkerhoff's original Acala 44 parent, which has no known genes for resistance to bacterial blight (14). The pyramiding strategy is illustrated in Figure 1.

Two nurseries were utilized to develop the initial $F_{1}$ and $F_{2}$ populations of the $B$ gene combinations (27). Later generations were advanced in growth chambers and greenhouses under BSL1-P biosafety guidelines (36).

Screening for resistance began in the $F_{2}$. Plants to be screened were raised in growth chambers with a ramped temperature and light program (31). Ac44E and the relevant parental single- $B$-gene NILs were included as checks in each chamber. Plantings were made in a peat/vermiculite mixture (Jiffy Mix Plus; Jiffy Products of America, Batavia, IL) in 7.6-liter pots. Seed were pretreated with a fungicide mixture of Demosan $65 \mathrm{~W}$ (chloroneb) and Arasan 76-S (thiram) (Dupont, Wilmington, DE). After emergence, seedlings were thinned to two plants per pot. At $\approx 8$ weeks, one young, well-expanded leaf per plant was spot-inoculated at

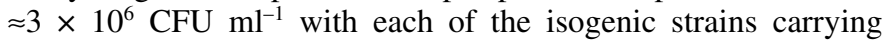
single or no $a v r$ genes and with race 1 strain $\mathrm{H}$, which carries $a v r$ genes recognized by each of the $R$ genes $B_{4}, B_{I n}$, and $b_{7}$. The inoculation pattern is illustrated in Figure 2 . At $\geq 14$ days postinoculation, plant responses were recorded based on degree of watersoaking using the five-point scale illustrated by Kangatharalingam et al. (21), where $0=$ no visible watersoaking and $4=$ confluent watersoaking. Plants exhibiting no visible watersoaking to a predicted subset of races were moved to the greenhouse and selfpollinated. Progeny from selected individual plants were raised in growth chambers and screened for resistance as described above. This process continued in each of the four pyramid lines until a uniform resistance phenotype was obtained in each (Table 1).

TABLE 1. Segregation analyses of pyramid lines prior to testing in the field

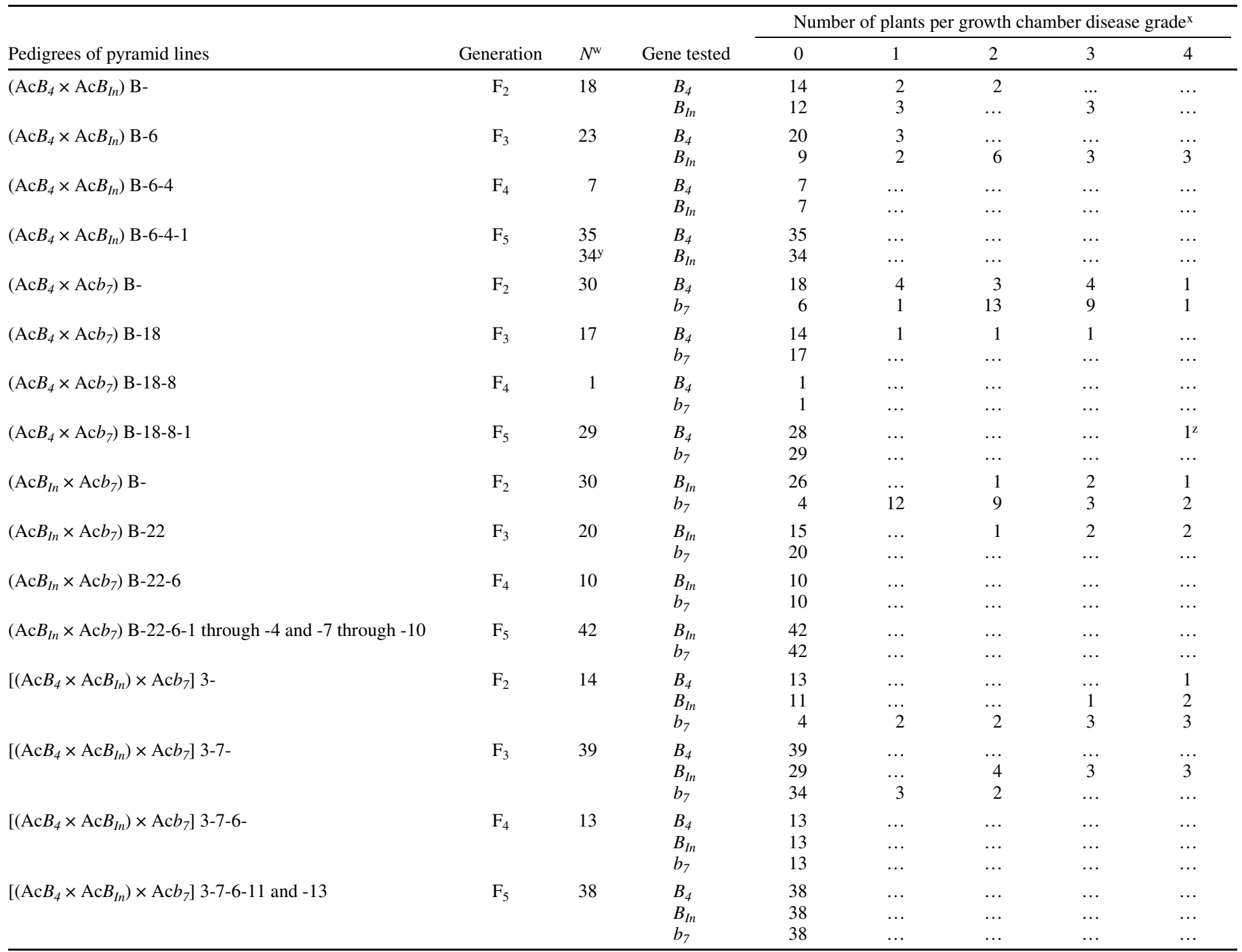

${ }^{\mathrm{w}}$ Number of plants tested.

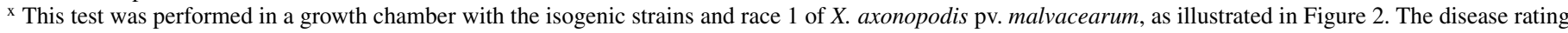
scale ranged from $0=$ no visible watersoaking to $4=$ confluent watersoaking (21).

y Part of the inoculated leaf on one plant was burned by the growth-chamber lights. Therefore, it was not possible to score that leaf for $B_{I n}$.

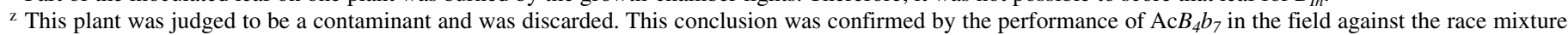
(Table 2). None of the 92 plants of $A c B_{4} b_{7}$ was as susceptible as any of the 81 plants of $A c b_{7}$. Thus, the $B 4$ gene in Ac $B_{4} b_{7}$ was not segregating. 
Note that the recessive gene $b_{7}$ was homozygous by the $\mathrm{F}_{3}$ generation in the two- $B$-gene pyramid lines which included it and by the $\mathrm{F}_{4}$ in the three- $B$-gene line. Also, note that the dominant genes $B_{4}$ and $B_{I n}$ were homozygous by the $\mathrm{F}_{4}$ generation in each of the four pyramid lines that included one or both of them; $B_{4}$ was homozygous in the $\mathrm{F}_{3}$ for $\left(\mathrm{Ac} B_{4} \times \mathrm{Ac} B_{I n}\right) \times \operatorname{Ac} b_{7}$. After a final evaluation of $\mathrm{F}_{5}$ progeny to ensure homozygosity for the expected $R$ genes, seed from the selected $\mathrm{F}_{5} \mathrm{~s}$ were bulked to form the final population for each pyramid line.

Three other pyramided lines were employed as checks in this study. In Im216, several major $R$ genes were backcrossed onto a polygenic complex background $(6,7)$. OK1.2 was derived from a cross between Ac44 and $\operatorname{Im} 216$ and is intermediate in resistance (29). AcHR ("Ac Highly Resistant"; formerly known as AcIm) was derived from a different cross between Ac44 and Im216, followed by a backcross to Ac44E (21).

Resistance evaluations in the field. Seed of each line in the pyramid were planted at Perkins, OK, under irrigation in 2002 in a randomized complete block experimental design with three replications. Individual plots were one row wide and $11 \mathrm{~m}$ long. Plants were thinned to a minimum spacing of $15 \mathrm{~cm}$. Eight weeks after planting, at the six- to eight-true-leaf stage, all plants within a plot were spray infiltrated with race $1\left(\approx 1 \times 10^{6} \mathrm{CFU} \mathrm{m}{ }^{-1}\right)$, as previously described (14). Plants were individually classified for disease reactions 2 to 3 weeks postinoculation, employing a disease index of $0=$ immune (no macroscopically visible symptoms) through 6 = fully susceptible (14). Two additional experiments were planted at Perkins in 2004 using a design and methodology similar to that of 2002, with three replications per experiment. AcHR and Im216 were also included as resistant checks. In one experiment, plants were treated with race 1 ; in the second, with a race mixture capable of infecting NILs with each of the individual $B$ genes. In each experiment, total inoculum concentration was $\approx 1 \times$ $10^{6} \mathrm{CFU} \mathrm{ml^{-1 }}$. The mixture contained approximately equal concentrations of race $1, \mathrm{KM} 1$, and race 10 . The experiments were analyzed separately using a randomized complete block analysis of variance for plot means (Statistix 9.0, Analytical Software, Tallahassee, FL) to determine whether there were statistical differences among lines.

In 2004, to test the qualitative responses of the pyramid lines to individual races of the mixture, five additional plants of each line within a single planting replication were spot inoculated with race $1, \mathrm{KM} 1$, and race 10 at 1 to $2.5 \times 10^{6} \mathrm{CFU} \mathrm{m}{ }^{-1}$ (four spots of each strain on each of two leaves per plant). Two weeks postinoculation, disease reactions were graded using the same scale as was employed in the growth chambers (21). The results were interpreted as resistant $=0$ to 1 and susceptible $=2$ to 4 .

Measurements of lesion size from the field. After leaves were examined in the field for disease index in $2002(\approx 1$ month after inoculation), two leaves were harvested from each of the first 20 plants in each replication (or from all plants if <20), placed in plastic bags on ice, and brought back to the laboratory for digital imaging. The abaxial surface of each leaf was scanned on an HP ScanJet IIc scanner (Hewlett-Packard Co., Palo Alto, CA), and the image was opened in Adobe Photoshop Elements 1.0 (Adobe Systems Inc., San Jose, CA). Within a representative area of a leaf, 10 typical lesions in a cluster were measured; excluded were those spreading along a leaf vein or touching one another. A onepixel pencil tool in off-white was used to outline the lesions in their outermost pixels (Fig. 3). The selected section of the image was saved and analyzed in NIH Image 1.61 (available online from the National Institutes of Health). The "density slice" tool enabled highlighting of the outlined lesions, and area measurements on the highlighted lesions were exported for statistical analysis. A mean lesion size was calculated for each plant. A randomized complete block analysis of variance (Statistix 9.0; Analytical Software) was performed on the log (mean lesion size) to determine whether there were statistical differences among lines.
Isolation and virulence testing of bacteria from large lesions collected during field evaluations. Unusually large lesions in Ac $B_{4} B_{I n} b_{7}$ were excised and homogenized in $\mathrm{CaCO}_{3}$ solution, and the homogenates were streaked on nutrient agar plates. Strains that produced glossy yellow colonies were purified by three sequential single-colony isolations. These isolates, along with race $1, \mathrm{KM} 1$, and race 10 , were spot-inoculated at concentrations of $1 \times 10^{6} \mathrm{CFU} \mathrm{m}{ }^{-1}$, as previously described (21), into leaves of the eight pyramid lines in a growth chamber. Progress of infections was evaluated using the watersoaking scale of Kangatharalingam et al. (21).

Bacterial populations in and on leaves in a growth chamber. The eight lines of the near-isogenic pyramid (Fig. 1), along with some older pyramided lines (Im216, AcHR, and, in all except experiment 1, OK1.2) were grown in growth chambers as described above, except 15 -cm-diameter clay pots were used and BSL-1-P containment was not. The central halves of recently expanded leaves (two leaves per plant and two plants per cotton line) were pressure-spray infiltrated with suspensions of $X$. axonopodis pv. malvacearum race 1 strain 3631 at $1 \times 10^{6} \mathrm{CFU} \mathrm{ml}{ }^{-1}$ in $\mathrm{CaCO}_{3}$ solution (28). In experiments 1 and 2 , populations were determined 8 and 9 days postinoculation, times at which maximum populations were expected (34). They were generally lower on day 9 than on day 8 (data not shown). To gather many replicate data from the most informative postinoculation time, the experiment was performed two more times, and data were taken only on day 8. On each sampling day, a random ordering of the 10 or 11 cotton lines was assigned. The first set of plants was sampled in that order, and then the duplicate set was sampled in reverse order so that each cotton line had the same average sampling time. Two 9-mm-diameter disks were harvested from each leaf (avoiding wilted or collapsed tissue as much as possible). Disks were placed in a closed test tube on ice until processing. Working in the same order as leaf sampling, each set of leaf disks was rinsed by vortexing for $30 \mathrm{~s}$ in $1.0 \mathrm{ml}$ of $\mathrm{CaCO}_{3}$ solution; the rinse was diluted in $\mathrm{CaCO}_{3}$ solution and plated in duplicate on nutrient agar. The rinsed disks were homogenized with mortar and pestle, and the homogenate was diluted in $\mathrm{CaCO}_{3}$ solution and plated in duplicate. Plating was completed within $8 \mathrm{~h}$ following harvest of the leaf disks. Average bacterial populations in the rinse solution and the homogenate were obtained for each leaf. These values were combined to produce a total average bacterial population for each leaf. Average populations for each plant were then determined. A completely randomized analysis of variance (Statistix 9.0; Analytical Software) was performed on the average log of the total population from each plant to determine whether there were statistical differences among lines.

\section{RESULTS}

Development of near-isogenic pyramid lines of cotton. When challenged with isogenic strains of $X$. axonopodis pv. malvacearum carrying specific cloned $a v r$ genes, individual $R$ genes were phenotypically expressed as predicted (14), as judged by ratios of resistance to susceptibility, regardless of the presence of other $R$ genes (Fig. 2). Thus, we were able to use the isogenic strains to screen for the presence of each $R$ gene, even in the presence of other $R$ genes.

Effects of gene pyramiding on bacterial blight symptoms in the field. In 2002, after inoculation with race $1, A c B_{4}$ and $A c b_{7}$ exhibited higher resistance (i.e., lower mean disease index) than $\operatorname{Ac} B_{I n}$ (Table 2). The three two- $B$-gene lines and the three- $B$-gene line, all of which possessed one or both of $B_{4}$ and $b_{7}$, were no more resistant to race 1 than $A c B_{4}$ and $A c b_{7}$ as measured by disease index, which is a visual assessment of lesion size and shape (14). More precise, digital measurements of lesion areas (Fig. 3) from a subset of those same leaves indicated that $A c b_{7}$ exhibited higher resistance to race 1 than both $\mathrm{Ac} B_{4}$ and $\mathrm{Ac} B_{I n}$. However, 
lesion areas indicated no gain in resistance by the two- $B$-gene and three- $B$-gene lines containing $b_{7}$ over the one- $B$-gene line Ac $b_{7}$. These relationships at the $P \leq 0.05$ level are illustrated in Figure 4 .

In 2004, the summer in north-central Oklahoma was cooler and wetter and bacterial blight was more severe than in 2002 for every cotton line. Under those conditions, $\mathrm{Ac} B_{4}$ exhibited the highest resistance of the one- $B$-gene lines to race 1 , followed by Ac $b_{7}$, then by $A c B_{I n}$ (Table 2). Small benefits of gene pyramiding were observed: $A c B_{I n} b_{7}$ exhibited significantly lower disease index to race 1 than either $A c B_{I n}$ or $A c b_{7}$, and the three- $B$-gene line Ac $B_{4} B_{I n} b_{7}$ exhibited a lower index than any one- $B$-gene line and than two of the two- $B$-gene lines (Table 2; Fig. 4). However, its disease index was not as low as that exhibited by Brinkerhoff's Im216 or by its derivative line, AcHR (Table 2, footnote v; Fig. 4).

In 2004, the pyramid lines were also challenged by inoculation with a mixture of $X$. axonopodis pv. malvacearum races. Spot inoculations in the field with those three individual races confirmed the predicted responses of the one- $B$-gene lines (Table 2). Spot inoculations of the pyramid lines elicited the qualitative responses expected if all $B$ genes were functioning. It was predicted that a pyramid line would be resistant to a given race if it contained at least one $B$ gene active against that race. All three two- $B$-gene lines were resistant to KM1 because $B_{I n}$ and $b_{7}$ are both active against KM1. $\mathrm{Ac} B_{4} B_{I n}$ and $\mathrm{Ac} B_{4} b_{7}$ were resistant to race 10 because they possess $B_{4}$. Ac $B_{I n} b_{7}$ was susceptible to race 10 , which is virulent toward both $B_{I n}$ and $b_{7}$. Ac $B_{4} B_{I n} b_{7}$ was resistant to all three races because none of them is virulent toward all three $B$ genes.

The quantitative measure of mean disease index of the pyramid lines to the race mixture matched exactly the predictions from the qualitative virulence and avirulence patterns of spot-inoculation results (Table 2). If a given line was susceptible to one or more components of the race mixture, the susceptible lesions dominated the observed disease index. The relative aggressiveness (relative ability to elicit disease symptoms in the absence of known $a v r-R$ gene interactions) of the three races in fully susceptible Ac44E was race $1>\mathrm{KM} 1>$ race 10 (data not shown).
The aggressiveness of the race 1 strain used was demonstrated in the only line susceptible to it, Ac44E, with a disease index of 5.4 on a 0.0 -to-6.0-point scale. $A c B_{4}$, which is susceptible to KM1, exhibited a disease index of 4.9 to the race mixture. The three lines that were susceptible to race 10 but resistant to KM1 exhibited more intermediate disease indexes of 3.5 to 4.0 , reflecting the lower aggressiveness of race 10, whose wide host range is due to its reduced number of $a v r$ genes. The three pyramid lines that were resistant to all three races exhibited still lower disease indexes of 2.2 to 2.5 , a highly resistant range of ink-dot to small, dry lesions (between Brinkerhoff's disease grades of 0.2 and 1.0) (7). Thus, resistance to the race mixture improved with pyramiding from susceptible to highly resistant but fell short of that exhibited by AcHR and Im216 (Fig. 4).

Virulence testing of bacteria from large lesions collected in the field evaluations. A scattering of unusually large watersoaked lesions was observed among the much more numerous small lesions on 11 of the $109 \mathrm{AcB}_{4} B_{I n} b_{7}$ plants that had been inoculated with the race mixture. Due to their low incidence, we suspected that those lesions were caused by race-change mutants $(5,9,24)$ within the inoculum rather than by any of the three strains of $X$. axonopodis pv. malvacearum used in the race mixture. For this

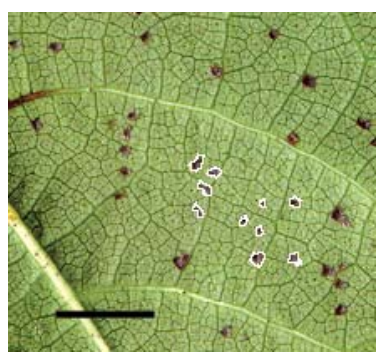

Fig. 3. Lesion size measurements. Typical lesions in field-inoculated cotton leaves were scanned on the abaxial side to provide a digital estimate of lesion size. A white outline of the outermost pixels of a lesion was used to determine the area of that particular lesion. The leaf section illustrated was from $\mathrm{Ac} B_{I n} b_{7}$ treated with Xanthomonas axonopodis pv. malvacearum race 1.

TABLE 2. Mean disease index, lesion size, and reaction to spot inoculations of pyramid lines of cotton containing various combinations of genes for bacterial blight resistance after inoculation in the field with selected races of Xanthomonas axonopodis pv. malvacearum ${ }^{s}$

\begin{tabular}{|c|c|c|c|c|c|c|c|c|}
\hline \multirow[b]{2}{*}{ Year, parameter measured } & \multicolumn{8}{|c|}{ Pyramid lines of cotton } \\
\hline & Ac44E & $\mathrm{Ac} B_{4}$ & $\mathrm{Ac} B_{I n}$ & $\mathrm{Ac} b_{7}$ & $\mathrm{Ac} B_{4} B_{I n}$ & $\mathrm{Ac} B_{4} b_{7}$ & $\mathrm{Ac} B_{I n} b_{7}$ & $\mathrm{Ac} B_{4} B_{I n} b_{7}$ \\
\hline \multicolumn{9}{|l|}{ 2002, Race 1} \\
\hline Lesion size $^{u}$ & $100.0 \mathrm{a}$ & $7.5 \mathrm{c}$ & $16.0 \mathrm{~b}$ & $4.8 \mathrm{~d}$ & $6.6 \mathrm{~cd}$ & $5.8 \mathrm{~cd}$ & $6.4 \mathrm{~cd}$ & $6.8 \mathrm{~cd}$ \\
\hline Number of plants & 5 & 48 & 48 & 36 & & & & \\
\hline \multicolumn{9}{|l|}{ 2004, Race $1^{\mathrm{v}}$} \\
\hline \multicolumn{9}{|c|}{ Reaction to spot inoculationsw } \\
\hline Race 1 & + & - & - & - & - & - & - & - \\
\hline KM1 & + & + & - & - & - & - & - & - \\
\hline Race 10 & + & - & + & + & - & - & + & - \\
\hline Number of plants & $4^{\mathrm{x}}$ & 5 & 5 & 5 & 5 & $4^{y}$ & 5 & 5 \\
\hline \multicolumn{9}{|l|}{ Race mixture ${ }^{\mathrm{z}}$} \\
\hline Disease index & $5.4 \mathrm{a}$ & $4.9 \mathrm{~b}$ & $3.5 \mathrm{~d}$ & $4.0 \mathrm{c}$ & $2.5 \mathrm{e}$ & $2.3 \mathrm{ef}$ & $3.6 \mathrm{~d}$ & $2.2 \mathrm{f}$ \\
\hline $\begin{array}{l}\text { respectively, with race } 1 \\
\text { indexes were statistically }\end{array}$ & $\leq 0.05) \mathrm{fr}$ & $\begin{array}{l}\text { exes of Ac } \\
\text { ach other a }\end{array}$ & ind $\operatorname{Im} 216$ & $\begin{array}{l}0.9(126 \\
\text { ther lines }\end{array}$ & and 0.5 & lants), resp & ely. With b & inocula, thos \\
\hline w Susceptible (+) or resista & & & & & & & & \\
\hline \multicolumn{9}{|c|}{ x Only four plants of Ac44E were scored because one plant's inoculated leaf abscised before its data could be collected. } \\
\hline y One of the five inoculate & 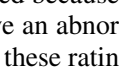 & usceptiole & Dit to & Deto & evious expe & e with Acl & that plant $\mathrm{V}$ & judged to be \\
\hline
\end{tabular}


reason, the large lesions were not included in the data summarized in Table 2. Bacteria isolated from large lesions in 7 of these $11 \mathrm{Ac} B_{4} B_{I n} b_{7}$ plants were tested by spot inoculation into the one- $B$-gene lines in a growth chamber along with controls of race $1, \mathrm{KM} 1$, and race 10 . The three control strains exhibited the same virulence and avirulence pattern as observed in the field (Table 2). In contrast, all seven isolates from the large lesions were virulent on all eight pyramid lines but avirulent in AcHR and $\operatorname{Im} 216$.

Bacterial populations in and on leaves in a growth chamber. At the dilute inoculum concentration used $\left(1 \times 10^{6} \mathrm{CFU} \mathrm{ml}{ }^{-1}\right)$, most leaf areas of lines other than $\mathrm{Ac} B_{I n}$ and $\mathrm{Ac} B_{I n} b_{7}$ retained turgor. Sample collection was complicated by a response of $A c B_{I n}$ and $A c B_{I n} b_{7}$ to spray inoculation in the growth chamber that had not been observed in the field with spray inoculation or in the growth chamber with spot inoculation. Approximately a week after inoculation, their leaves began to collapse, lose chlorophyll, and dry. Bacterial populations in collapsed and dried tissues were lower than those from turgid tissue (data not shown); therefore, samples were, as much as possible, taken from still-turgid areas of the affected leaves. $A c B_{I n} b_{7}$ exhibited nearly as much spreading collapse as $A c B_{I n}$. However, collapse was much less marked in $\mathrm{Ac}_{4} B_{\text {In }}$ and was not observed at all in $\mathrm{Ac} B_{4} B_{I n} b_{7}$.

A combined analysis across experiments indicated that there was no significant experiment-to-experiment variance among experiments 2 through 4 (performed in September and December
2002

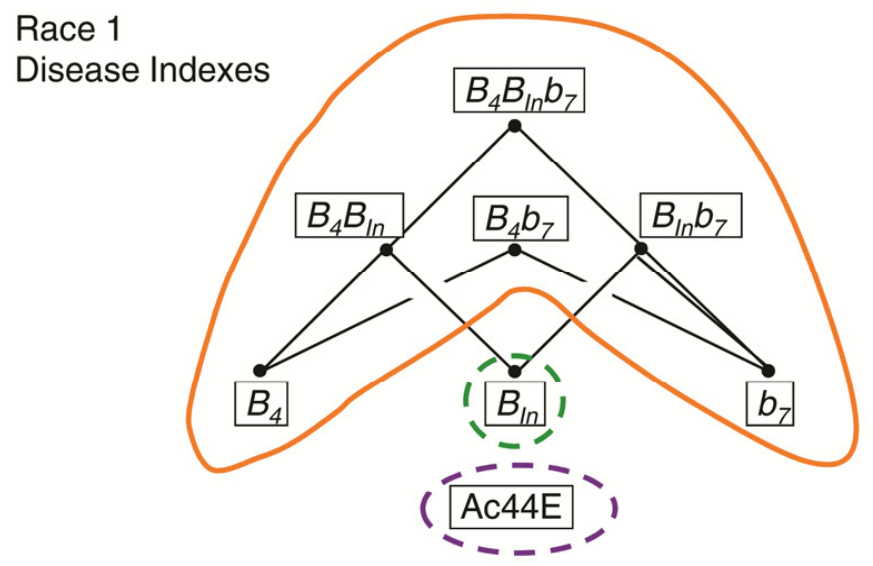

\section{4}

Range of means represented Race 1
Disease Indexes

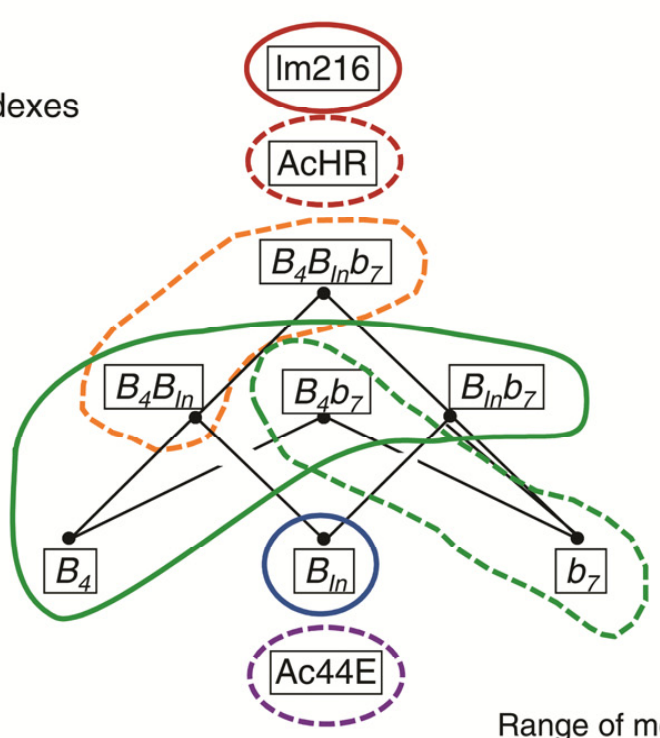

\section{Disease Indexes}

Race 1
Lesion Sizes

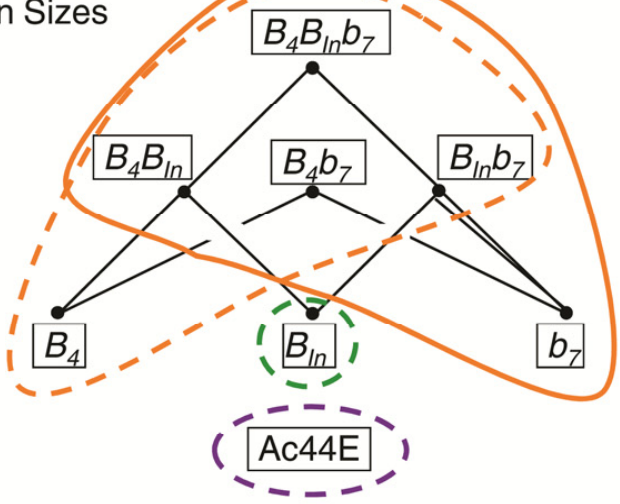

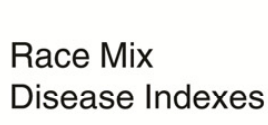

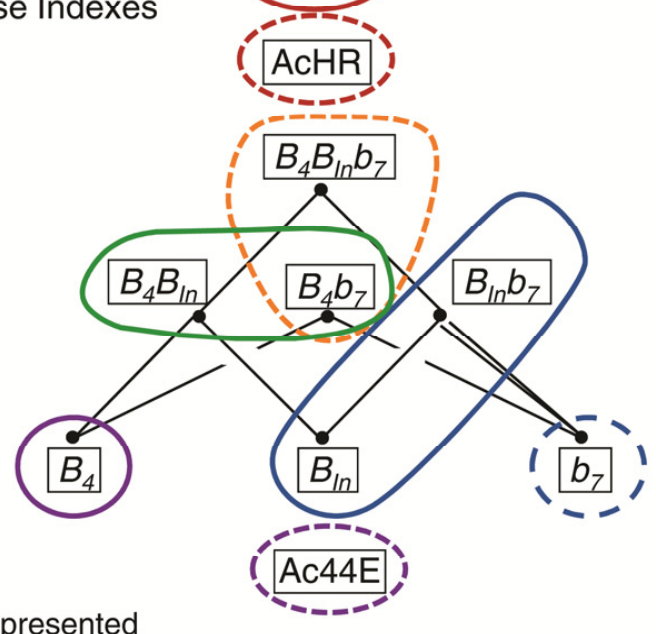

$\begin{array}{ll}\text { Disease } & \text { Lesion sizes } \\ \text { indexes } & \text { (\% of Ac44E) }\end{array}$

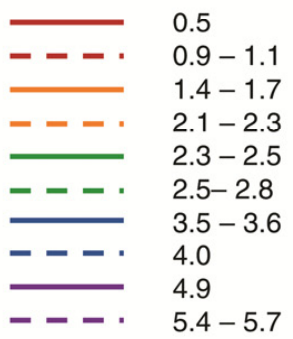

$4.8-6.8$
$5.8-7.5$
16
100

Fig. 4. Disease development in the field in the $B$-gene pyramid near-isogenic lines (NILs) plus AcHR and Im216. Cotton NILs enclosed by a line of a given color and type (solid or dashed) were not significantly different from each other $(P \leq 0.05)$ in resistance to Xanthomonas axonopodis pv. malvacearum. 
2004) but there was between them and experiment 1 (performed in July 2003). Therefore, results of experiment 1 are presented separately from those of experiments 2 through 4 (Fig. 5A and B, respectively).

In experiment 1 (Fig. 5A), a beneficial effect of gene pyramiding on bacterial populations was observed. Two two- $B$-gene lines $\left(\mathrm{Ac} B_{I n} b_{7}\right.$ and $\left.\mathrm{AcB}_{4} B_{I n}\right)$ had significantly lower 8-day
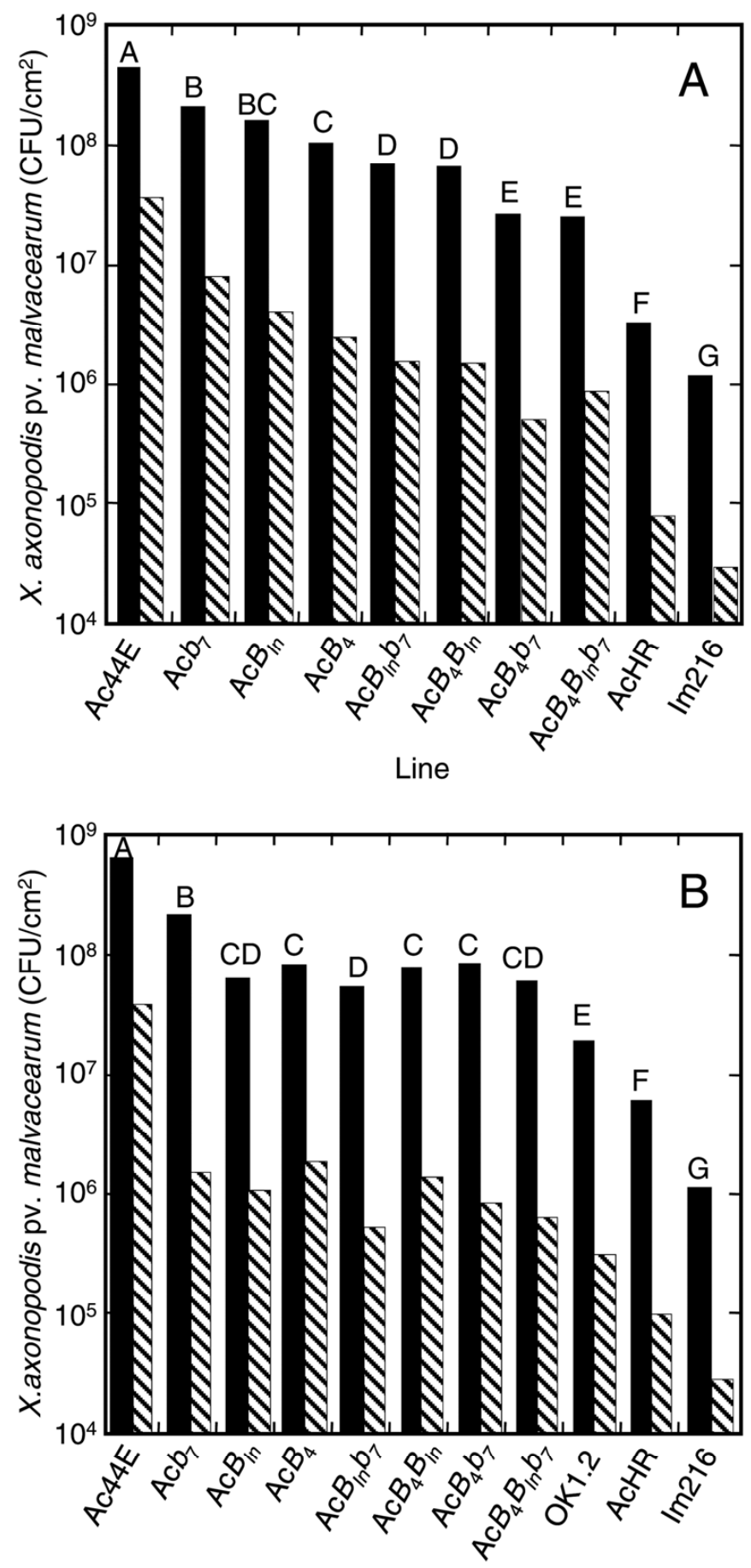

Line

Fig. 5. Populations of Xanthomonas axonopodis pv. malvacearum strain 3631 in and on leaves of the $B$-gene pyramid near-isogenic lines plus AcHR, Im216, and (in B) OK1.2 at 8 days postinoculation in a growth chamber. A, Experiment 1 (in 2003); B, means of experiments 2, 3, and 4 (in 2004). Inoculum concentrations were $\approx 1 \times 10^{6} \mathrm{CFU} \mathrm{ml}{ }^{-1}$. Dark bars show mean $\log _{10}$ (total population in homogenate + rinse); diagonally shaded bars show the contribution from the rinse. The same letters above the dark columns indicate groups that were not significantly different from each other $(P \leq 0.05)$. bacterial populations than any of the one- $B$-gene lines, and the other two- $B$-gene line $\left(\mathrm{Ac} B_{4} b_{7}\right)$ and the three- $B$-gene line $\left(\mathrm{Ac} B_{4} B_{I n} b_{7}\right)$ had significantly lower populations still. However, we were unable to reproduce those observations. In experiments 2,3 , and 4 (Fig. 5B), none of the two- or three- $B$-gene pyramid lines had a significantly lower bacterial population than the most resistant of its related one- $B$-gene lines (Fig. 5B).

In contrast, the older pyramided line developed by Brinkerhoff, Im216, had only 2 to $5 \%$ of the bacterial population attained in the three- $B$-gene line $A c B_{4} B_{I n} b_{7}$ (Fig. 5A and B). The lines AcHR and $\mathrm{OK} 1.2$, which were derived from crosses between $\operatorname{Im} 216$ and Ac44, had intermediate populations, significantly lower than those in the three- $B$-gene line but higher than those in $\operatorname{Im} 216$ and distinct from each other (Fig. 5A and B).

Populations of $X$. axonopodis pv. malvacearum rinsed from leaf surfaces were higher on fully susceptible Ac44E than on any resistant line. When considered as fractions of the total bacterial populations, the data fell into two groups: Ac44E versus all resistant and immune lines. On the Ac44E leaves, rinsed populations were 8 to $9 \%$ of the total populations whereas, on the other lines, rinsed populations were only 1 to $4 \%$ of their respective total populations.

\section{DISCUSSION}

The unexpected outcome of this work was that pyramiding three race-specific $R$ genes into a single susceptible cotton line gave only a small or undetected enhancement in the level of resistance toward race 1 , a race of the pathogen carrying all three corresponding $a v r$ genes. The enhancement was only detected under certain conditions: the cool, wet field conditions of 2004 (but not the warmer, drier season of 2002) and the growth chamber conditions of experiment 1 (performed in July 2003) but not those of experiments 2, 3, and 4 (performed in September and December 2004).

The situation was not that higher levels of resistance were difficult to observe: in the field, AcHR and Im216 exhibited mean disease indexes that were significantly different from each other and significantly lower than those of any of the Acala pyramid lines (Table 2, footnote v; Fig. 4). In growth chambers, lines OK1.2, AcHR, and Im216 arrested bacterial multiplication at population levels that were not only significantly lower than those in the three- $B$-gene pyramid line but also significantly different from each other (Fig. 5).

Precedents exist in other host-pathogen systems for both high levels of increase and also little or no increase in resistance level by gene pyramiding. Pyramids were constructed from NILs in rice (Oryza sativa L.) on two genetic backgrounds with genes for resistance to $X$. oryzae pv. oryzae $(16,35)$. With both pyramids, some combinations of $R$ genes gave higher levels of resistance (i.e., shorter lesion lengths) than did single genes $(16,19,20,35)$. However, other gene combinations failed to do so. For instance, the two- $R$-gene line IRBB55 carrying $x a 13$ and $\mathrm{Xa21}$ was as resistant to the highly virulent Indian isolate Kaul as lines carrying one or two additional genes ( $x a 5$ or $X a 4+x a 5)(20)$. In a large study that tested all one-, two-, three-, and four- $R$-gene combinations of $X a 4, x a 5, x a 13$, and $X a 21$ against 16 Korean isolates, the two- $R$-gene combination $\mathrm{Xa} 4$ plus $\mathrm{Xa21}$ conferred higher resistance toward most of the isolates than either single $R$ gene; however, the rest of this large dataset contained more cases where gene pyramiding did not significantly enhance level of resistance than cases where it did (19).

Another precedent was noted with bell pepper (Capsicum annuиm L.), where a pyramid set of lines that had been built from NILs was evaluated for resistance to six races of $X$. axonopodis pv. vesicatoria (22). The authors' interest was in the residual effects of defeated genes. They found that, when deployed in combinations, the area under the disease progress curve (AUDPC) 
was less than with genes deployed individually. However, their data (Table 3 of Kousik and Ritchie [22]) showed that pairs of undefeated genes $(B s 1+B s 2$ toward race 2 or $B s 2+B s 3$ toward race 1) resulted in AUDPC values no lower than the single genes (22).

We propose the following model as a possible explanation for the observation of little or no increase in level of resistance with gene pyramiding. Using the gene names of the cotton- $X$. axonopodis pv. malvacearum system as examples, each of the $a v r$ genes $a v r B 4, a v r B I n$, and $a v r b 7$ is a race-specific $a v r$ gene that encodes an effector that triggers a resistant response only in cotton plants possessing the corresponding $R$ gene. Those three effectorreceptor interactions may activate a common signal transduction pathway that leads to the resistant response of phytoalexin biosynthesis, hypersensitive cell death, and so on. When the most active of the $R$ genes ( $b_{7}$ in the field conditions of 2002 and $B_{4}$ in 2004) encounters its respective effector from race 1, it may generate so much of a downstream component of the pathway that the pathway is saturated (i.e., it is functioning at its maximum rate). Adding another effector-receptor interaction upstream would not make the pathway work any faster; therefore, the plant's resistant response would be no more effective.

We must also account for the fact that AcHR and Im216 exhibit higher levels of resistance to the same pathogen (X. axonopodis pv. malvacearum race 1). AcHR and $\operatorname{Im} 216$ each possesses multiple $R$ genes that are different from the ones pyramided into $\operatorname{Ac} B_{4} B_{I n} b_{7}$. These other $R$ genes may activate additional signal transduction pathways. $X$. axonopodis pv. malvacearum race 1 possesses many more (at least 10) than the three $a v r$ genes recognized by $A c B_{4} B_{I n} b_{7}$ (41) and, therefore, presumably produces many more than three kinds of effectors. When race 1 infects AcHR and $\operatorname{Im} 216$, such additional signal transduction pathways may be activated and may lead to a quicker, more effective resistant response than the pathway activated by $B_{4}, B_{I n}$, and $b_{7}$ is able to achieve alone.

However, it seems more likely to us that the additional resistance of $\operatorname{Im} 216$ is not qualitatively different from that of the NILs, just quicker. In a separate study with five of the same lines employed here, which ranged in level of bacterial blight resistance from susceptible (Ac44E) through moderately resistant $\left(\mathrm{Ac} B_{I n}\right.$ and $\left.\mathrm{AcB} B_{4}\right)$ to highly resistant (AcHR) and immune (Im216), we observed the kinetics of expression after inoculation with race 1 of four defense genes (Supplemental Figure 1). Those genes were chosen to represent different aspects of defense: a transcription factor, a lipoxygenase, a phytolexin biosynthetic enzyme, and a pathogenesis-related (PR) protein. Transcript levels of all four of these diverse defense genes increased after inoculation with race 1 in the four resistant lines; however, this increase occurred much more quickly in Im216 and AcHR than in $\mathrm{Ac} B_{4}$ and $\mathrm{Ac} B_{I n}$.

The observation in the present study that pyramiding three $B$ genes did not markedly increase the level of resistance suggests to us that the polygenic resistant background of $\operatorname{Im} 216$, some of which it contributed to its derivatives AcHR and OK1.2, accelerates the plant's response via the common pathway proposed above. For instance, a modifier gene might somehow increase the binding affinities of the $B_{4}, B_{I n}$, and $b_{7}$ receptors for their respective $a v r$ gene effectors so that the receptors become activated at lower concentrations of the effectors and, therefore, activate the common resistance pathway more quickly.

The predicted increase in breadth of resistance was achieved by pyramiding $B_{4}, B_{I n}$, and $b_{7}$. The observation that disease index of a cotton line to the race mixture was dominated by the most virulent component of the race mixture indicates that, under the conditions of our field tests, the presence of avirulent bacteria in the mixture (e.g., race 1) did not prevent virulent bacteria from inciting disease lesions. The $B$ genes introduced resistance to those virulent races $\left(B_{I n}\right.$ and $b_{7}$ to KM1 and $B_{4}$ to race 10) and thereby increased the resistance levels of the pyramid lines to the race mixture (Table 2; Fig. 4).

The bacteria isolated from the large lesions in $A c B_{4} B_{I n} b_{7}$ plants that were inoculated with the race mixture exhibited the phenotype expected of race 18 , which differs from race 10 in being virulent against $B_{4}(4,17)$. They were probably race-change mutants from race 10 . We cannot be certain of this origin because the strain of race 10 included in the race mixture carried no genetic markers for which we could easily test. However, as shown in Table 2, race 10 is virulent against $B_{I n}$ and $b_{7}$. Thus, a single mutation in race 10 that caused loss of function of $a v r B_{4}$ would make it virulent against all eight pyramid lines of Table 2. Race-change mutations in $X$. axonopodis pv. malvacearum occur readily, although they have never been observed to confer virulence against AcHR or $\operatorname{Im} 216(5,9,24)$.

A gene designated $B_{12}$ has been identified that confers resistance to all races of $X$. axonopodis pv. malvacearum identified in the Americas, including race 18 (38). Recently, molecular markers for $B_{12}$ have been identified (40), which will facilitate selection for this gene in breeding programs. However, the ease with which race-change mutants of $X$. axonopodis pv. malvacearum appear against $B_{4}, B_{I n}, b_{6}$, and $b_{7}(5,9,24)$ indicates that breeders should not rely upon $B_{12}$ alone unless there is good evidence that it is much more durable than those $B$ genes.

The spreading collapse of spray-inoculated $A c B_{I n}$ and $A c B_{I n} b_{7}$ leaves under growth-chamber conditions appears to be a defense response conditioned by $B_{\text {In }}$ that is out of control. It did kill pathogenic bacteria: the populations attained by 8 to 9 days postinoculation (Fig. 5) fell as leaves collapsed and dried. It did so at high cost, however, because nearly the entire inoculated area of the leaf died. Leaves of other cotton lines in this study tolerated spray inoculation with this dilute inoculum $\left(\approx 1 \times 10^{6} \mathrm{CFU} \mathrm{ml}{ }^{-1}\right)$, developing varying degrees of chlorosis and reddening $(13,21)$ but remaining turgid through the 8- to 9-day experiments. In the more susceptible of those leaves (Ac44E and Ac $b_{7}$ ), spreading infections had not yet killed the leaves. In the other resistant leaves, tissues surrounding each microscopic hypersensitive response (15) still remained alive. The spreading collapse in $\mathrm{Ac} B_{I n}$ and $\operatorname{Ac} B_{I n} b_{7}$ might be caused by an oxidative burst that results from the $a v r B I n-B_{I n}$ interaction and is somewhat like the "runaway cell death" triggered by superoxide ions in $l s d l$ mutants of Arabidopsis thaliana (18). In our gene expression study discussed above, transcript levels of the four defense genes studied had gone through their maxima or leveled off in $\operatorname{Im} 216$, $\mathrm{AcHR}$, and $\mathrm{AcB}_{4}$ (with the single exception of $G h C Y P 706 B 1$ in $\mathrm{Ac} B_{4}$ ). However, in $\mathrm{Ac} B_{I n}$, transcript levels of all four genes, which included the plant-membrane-damaging lipoxygenase Ghkloxl (12,33), were still rising at the last time point, $96 \mathrm{~h}$ postinoculation. We suggest that the signal that results from the avrBIn- $B_{I n}$ interaction is especially persistent in $\mathrm{Ac} B_{I n}$ and $\mathrm{Ac} B_{I n} b_{7}$ and leads to the spreading tissue collapse that we observed. In plants that possessed $B_{4}$ in addition to $B_{I n}$, that signal was somehow suppressed when they were inoculated with race 1 , which carries both avrBIn and $a v r B 4$.

The lower numbers of bacteria that reach the leaf surface in bacterial blight-resistant plants than in susceptible plants are an important benefit of resistance. In the field, bacteria on leaf surfaces are carried by wind or rain-splash to other leaves of the same plant or to other plants. In susceptible plants such as Ac44E, bacterial blight causes watersoaked leaf spots in which the entire intercellular space of the infected area is filled with bacterial extracellular polysaccharide slime that contains suspended bacteria (2). This slime oozes from open stomata onto leaf surfaces. The loss of turgor that accompanies the disease decreases the volume of intercellular space (32) and may exacerbate this effect. In leaves of resistant plants, bacterial populations are lower (Fig. 5) and turgor is maintained longer. Bacterial populations on resistant leaves, as indicated by bacteria that were rinsed from the leaf 
samples, were one to three orders of magnitude lower than those on susceptible leaves (Fig. 5) and represented smaller percentages of the total bacterial populations as well.

We did not succeed in duplicating the pyramiding success of Brinkerhoff with $\operatorname{Im} 216$. The small increases in level of bacterial blight resistance to race 1, which were not always detected, show that not all $R$ genes give substantial, additive benefits when combined. We did, however, extend the breadth of resistance to the race mixture exactly as predicted. In many plant-pathogen systems, more need exists for durability of resistance than for enhanced level of resistance. Durable and very high resistance was achieved in cotton line $\operatorname{Im} 216$ and its sister lines by pyramiding genes that, together, confer resistance to a wide range of races onto a polygenic resistant background $(3,7)$. $R$ genes vary greatly in durability, and the most durable seem to be those that impose a high pathogenic fitness penalty upon the pathogen races that adapt to them $(23,25)$. Thus, for durability of disease resistance, the particular $R$ genes chosen for use in a breeding program matter more than their number. The results reported here demonstrate that this is also true if one wants to increase the level of resistance.

\section{ACKNOWLEDGMENTS}

This research was supported by the National Research Initiative Competitive Grants Program-United States Department of Agriculture award 9702743 and by the Oklahoma Agricultural Experiment Station Project OKL01504. We thank M. E. Bayles, J. A. Hall, and C. Hager for technical assistance; and T. A. Wheeler and D. W. Gabriel for reviews of our original manuscript.

\section{LITERATURE CITED}

1. Allard, R. W. 1960. Pedigree method of plant breeding. Pages 115-128 in: Principles of Plant Breeding. John Wiley \& Sons, Inc., New York.

2. Al-Mousawi, A. H., Richardson, P. E., Essenberg, M., and Johnson, W. M. 1982. Ultrastructural studies of a compatible interaction between Xanthomonas campestris pv. malvacearum and cotton. Phytopathology 72:12221230.

3. Bird, L. S. 1982. The MAR (multi-adversity resistance) system for genetic improvement of cotton. Plant Dis. 66:172-176.

4. Bird, L. S., and Tsai, A. 1975. A new race of Xanthomonas malvacearum. Pages 9-10 in: (Abstr.) Proc. Beltwide Cotton Prod. Res. Conf. New Orleans.

5. Brinkerhoff, L. A. 1970. Variation in Xanthomonas malvacearum and its relation to control. Annu. Rev. Phytopathol. 8:85-110.

6. Brinkerhoff, L. A., and Verhalen, L. M. 1976. Inheritance of immunity to bacterial blight in an upland cotton cross. Page 31 in: (Abstr.) Proc. Beltwide Cotton Prod. Res. Conf. Las Vegas, NV.

7. Brinkerhoff, L. A., Verhalen, L. M., Johnson, W. M., Essenberg, M., and Richardson, P. E. 1984. Development of immunity to bacterial blight of cotton and its implications for other diseases. Plant Dis. 68:168173.

8. Cote, R., Daggett, P.-M., Gantt, M. J., Hay, R., Jong, S.-C., and Pienta, P., eds. 1984. ATCC Media Handbook. American Type Culture Collection, Rockville, MD.

9. De Feyter, R., and Gabriel, D. W. 1991. At least six avirulence genes are clustered on a 90-kilobase plasmid in Xanthomonas campestris pv. malvacearum. Mol. Plant-Microbe Interact. 4:423-432.

10. DeFeyter, R., Kado, C. I., and Gabriel, D. W. 1990. Small, stable shuttle vectors for use in Xanthomonas. Gene 88:65-72.

11. De Feyter, R., Yang, Y., and Gabriel, D. W. 1993. Gene-for-genes interactions between cotton $R$ genes and Xanthomonas campestris pv. malvacearum avr genes. Mol. Plant-Microbe Interact. 6:225-237.

12. Delannoy, E., Lyon, B. R., Marmey, P., Jalloul, A., Daniel, J. F., Montillet, J. L., Essenberg, M., and Nicole, M. 2005. Resistance of cotton towards Xanthomonas campestris pv. malvacearum. Annu. Rev. Phytopathol. 43:63-82.

13. Edwards, W. R., Hall, J. A., Rowlan, A. R., Schneider-Barfield, T., Sun, T. J., Patil, M. A., Pierce, M. L., Fulcher, R. G., Bell, A. A., and Essenberg, M. 2008. Light filtering by epidermal flavonoids during the resistant response of cotton to Xanthomonas protects leaf tissue from lightdependent phytoalexin toxicity. Phytochemistry 69:2320-2328.

14. Essenberg, M., Bayles, M. B., Samad, R. A., Hall, J. A., Brinkerhoff, L. A., and Verhalen, L. M. 2002. Four near-isogenic lines of cotton with different genes for bacterial blight resistance. Phytopathology 92:13231328.

15. Essenberg, M., Cason, E. T., Jr., Hamilton, B., Brinkerhoff, L. A., Gholson, R. K., and Richardson, P. E. 1979. Single cell colonies of Xanthomonas malvacearum in susceptible and immune cotton leaves and the local resistant response to colonies in immune leaves. Physiol. Plant Pathol. 15:53-68.

16. Huang, N., Angeles, E. R., Domingo, J., Magpantay, G., Singh, S., Zhang, G., Kumaravadivel, N., Bennett, J., and Khush, G. S. 1997. Pyramiding of bacterial blight resistance genes in rice: Marker-assisted selection using RFLP and PCR. Theor. Appl. Genet. 95:313-320.

17. Hussain, T., and Brinkerhoff, L. A. 1978. Race 18 of the cotton bacterial blight pathogen, Xanthomonas malvacearum, identified in Pakistan in 1977. Plant Dis. Rep. 62:1085-1087.

18. Jabs, T., Dietrich, R. A., and Dangl, J. L. 1996. Initiation of runaway cell death in an Arabidopsis mutant by extracellular superoxide. Science 273:1853-1856.

19. Jeung, J. U., Heu, S. G., Shin, M. S., Vera Cruz, C. M., and Jena, K. K. 2006. Dynamics of Xanthomonas oryzae pv. oryzae populations in Korea and their relationship to known bacterial blight resistance genes. Phytopathology 96:867-875.

20. Joseph, M., Gopalakrishnan, S., Sharma, R. K., Singh, V. P., Singh, A. K., Singh, N. K., and Mohapatra, T. 2004. Combining bacterial blight resistance and basmati quality characteristics by phenotypic and molecular marker-assisted selection in rice. Mol. Breed. 13:377-387.

21. Kangatharalingam, N., Pierce, M. L., Bayles, M. B., and Essenberg, M. 2002. Epidermal anthocyanin production as an indicator of bacterial blight resistance in cotton. Physiol. Mol. Plant Pathol. 61:189-195.

22. Kousik, C. S., and Ritchie, D. F. 1999. Development of bacterial spot on near-isogenic lines of bell pepper carrying gene pyramids composed of defeated major resistance genes. Phytopathology 89:1066-1072.

23. Leach, J. E., Vera Cruz, C. M., Bai, J., and Leung, H. 2001. Pathogen fitness penalty as a predictor of durability of disease resistance genes. Annu. Rev. Phytopathol. 39:187-224.

24. McNally, K. L. 1990. Useful minimal medium for growth of Xanthomonas campestris pv. malvacearum, molecular biological analysis of avirulence in $\mathrm{Xcm}$, and identification of multiple resistance genes in the segregating Gossypium hirsutum line Acala $\mathrm{B}_{5}$. Ph.D. dissertation, Oklahoma State University, Stillwater.

25. Mundt, C. C. 1990. Probability of mutation to multiple virulence and durability of resistance gene pyramids. Phytopathology 80:221-223.

26. Nelson, R. R. 1978. Genetics of horizontal resistance to plant diseases. Annu. Rev. Phytopathol. 16:359-378.

27. O'Brien, D. 2010. Tropical treasure turns 60. Agric. Res. 58:18.

28. Patil, M. A., Pierce, M. L., Phillips, A. L., Venters, B. J., and Essenberg, M. 2005. Identification of genes up-regulated in bacterial-blightresistant upland cotton in response to inoculation with Xanthomonas campestris pv. malvacearum. Physiol. Mol. Plant Pathol. 67: 319-335.

29. Pierce, M., and Essenberg, M. 1987. Localization of phytoalexins in fluorescent mesophyll cells isolated from bacterial blight-infected cotton cotyledons and separated from other cells by fluorescence-activated cell sorting. Physiol. Mol. Plant Pathol. 31:273-290.

30. Pierce, M. L., Cover, E. C., Richardson, P. E., Scholes, V. E., and Essenberg, M. 1996. Adequacy of cellular phytoalexin concentrations in hypersensitively responding cotton leaves. Physiol. Mol. Plant Pathol. 48:305-324.

31. Pierce, M. L., Essenberg, M., and Mort, A. J. 1993. A comparison of the quantities of exopolysaccharide produced by Xanthomonas campestris pv. malvacearum in susceptible and resistant cotton cotyledons during early stages of infection. Phytopathology 83:344-349.

32. Popham, P. L., Pike, S. M., Novacky, A., and Pallardy, S. G. 1993. Water relation alterations observed during hypersensitive reaction induced by bacteria. Plant Physiol. 103:1243-1247.

33. Sayegh-Alhamdia, M., Marmey, P., Jalloul, A., Champion, A., Petitot, A. S., Clerivet, A., and Nicole, M. 2008. Association of lipoxygenase response with resistance of various cotton genotypes to the bacterial blight disease. J. Phytopathol. 156:542-549.

34. Shevell, J. L. 1985. Phytoalexin production in congenic cotton lines challenged with races of Xanthomonas campestris pv. malvacearum. M.S. thesis, Oklahoma State University, Stillwater.

35. Singh, S., Sidhu, J. S., Huang, N., Vikal, Y., Li, Z., Brar, D. S., Dhaliwal, H. S., and Khush, G. S. 2001. Pyramiding three bacterial blight resistance genes (xa5, xa13 and $\mathrm{Xa21}$ ) using marker-assisted selection into indica rice cultivar PR106. Theor. Appl. Genet. 102:1011-1015.

36. Southwestern OK State Univ. 2003. SWOSU Biosafety guidelines. www.swosu.edu/resources/pubforms/DisplayMedia. aspx?pid=440

37. U.S. Dep. Health and Human Services. 2009. Biosafety in Microbiological and Biomedical Laboratories, 5th ed. HHS Publ. No. (CDC) 21-1112. 
38. Wallace, T. P., and El-Zik, K. M. 1989. Inheritance of resistance in three cotton cultivars to the HV1 isolate of bacterial blight. Crop Sci. 29:11141119.

39. Wright, R. J., Thaxton, P. M., El-Zik, K. M., and Paterson, A. H. 1998. Dsubgenome bias of $\mathrm{Xcm}$ resistance genes in tetraploid Gossypium (cotton) suggests that polyploid formation has created novel avenues for evolution. Genetics 149:1987-1996.
40. Xiao, J., Fang, D. D., Bhatti, M., Hendrix, B., and Cantrell, R. 2010. A SNP haplotype associated with a gene resistant to Xanthomonas axonopodis pv. malvacearum in upland cotton (Gossypium hirsutum L.). Mol. Breed. 25:593-602.

41. Yang, Y., Yuan, Q., and Gabriel, D. W. 1996. Watersoaking function(s) of XcmH1005 are redundantly encoded by members of the Xanthomonas avr/pth gene family. Mol. Plant-Microbe Interact. 9:105-113. 